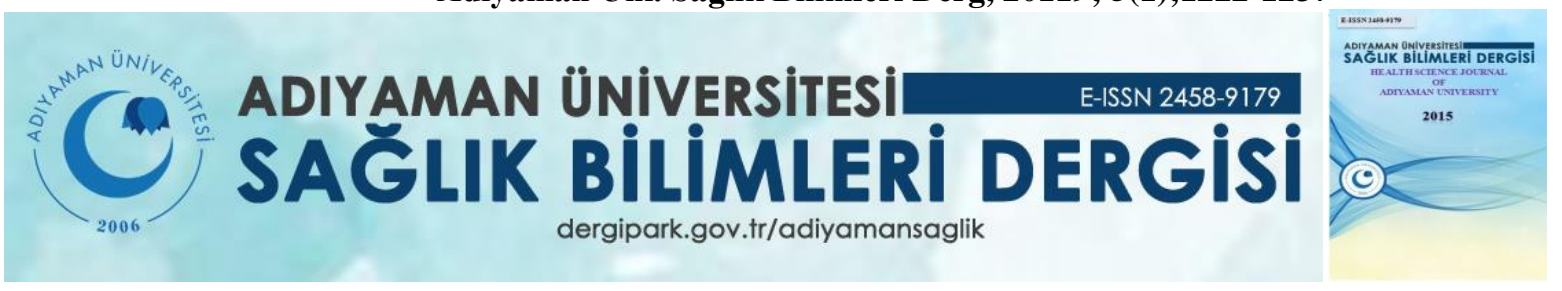

\title{
Araștırma/Research \\ Günübirlik Cerrahide Hasta Konforu ve Hasta Konforunu Etkileyen Etmenler
}

\author{
Havva YÖNEM AMAÇ ${ }^{1}$ Rahşan ÇAM ${ }^{1}$ \\ ${ }^{1}$ Aydın Adnan Menderes Üniversitesi Hemirelik Fakültesi Cerrahi Hastalıkları Hemşireliği Anabilim Dalı, \\ Aydın, Türkiye
}

\section{$\ddot{O} \mathbf{z}$}

Giriş: Günübirlik cerrahi, uygun hastaların aynı gün içinde ameliyat olarak taburcu oldukları cerrahi girişimlerdir. Cerrahi tekniklerde ve anestezi tekniklerinde yaşanan gelişmeler sayesinde günübirlik cerrahi birçok ülkede hızla yayılmıștır. Günübirlik cerrahi her geçen gün daha fazla vakada daha çok hastaya uygulanmaktadır. Konfor, hemşirelik bakımının beklenen bir sonucudur. Hasta konforunun değerlendirilmesi daha iyi bir hemşirelik bakımı sağlayabilmek için gereklidir.

Amaç: Bu araştırma günübirlik cerrahi hastalarında konfor ve konforu etkileyen etmenleri belirlemek amacıyla yapılmıştır.

Yöntem: Araştırmaya günübirlik cerrahi amacıyla günübirlik cerrahi servisine yatışı yapılan 300 hasta dahil edilmiştir. Araştırma verilerinin toplanmasında Bireysel Özellikler Formu, Perianestezi Konfor Ölçeği Formu ve Durumluk-Sürekli Kaygı Ölçeği Formu kullanılmıştır.

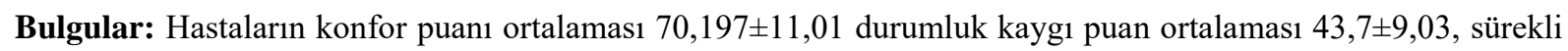
kayg1 puan ortalaması $46,77 \pm 7,51$ olarak bulunmuştur.

Sonuç: Hasta konforunun yapılacak cerrahi ile ilgili bilgi verilme zamanı, daha önceden hastane deneyimi bulunma gibi değişkenlere göre farklılık gösterdiği, hastaların yaş, kronik hastalık varlığı, eğitim durumu gibi değişkenlere göre kaygı puanlarının farklılık gösterdiği ancak konfor puan ortalamalarının farklılık göstermediği sonucuna ulaşılmıştır.

Anahtar Kelimeler: Günübirlik cerrahi, hasta konforu, hemşirelik.

Aydın Adnan Menderes Üniversitesi Sağllk Bilimleri Enstitüsü Cerrahi Hastallkları Hemşireliği Yüksek Lisans Programı Yüksek Lisans Tezi, Kabul Tarihi: Ağustos, 2016.

Çalışma 4-7 Mayıs 2017 tarihinde Yunanistan'ın Rodos adasında düzenlenen '8 th 8th Congress of the European Operating Room Nurses Association (EORNA)' kongresinde poster bildiri olarak sunulmuştur.

\begin{tabular}{l}
\hline Yazışmadan Sorumlu Yazar \\
\hline Havva YÖNEM AMAÇ \\
Aydın Adnan Menderes Üniversitesi Hemirelik \\
Fakültesi Cerrahi Hastalıkları Hemşireliği \\
Anabilim Dalı, Aydın, Türkiye \\
Tel : +90 5383936198 \\
Email: havvaynm@hotmail.com \\
\hline
\end{tabular}

\section{Doi:10.30569.adiyamansaglik.481605}

\begin{tabular}{ll}
\hline Geliş Tarihi: & 12.11 .2018 \\
\hline Kabul Tarihi: & 31.01 .2019 \\
\hline
\end{tabular}


The Patient Comfort in Day Surgery Patients and Factors Affecting the Patient Comfort

\begin{abstract}
Background: Day surgery is a surgery that the patients are discharged on the same day. Thanks to developments in anesthesia and surgical techniques, ambulatory surgery has spread rapidly in many countries. Day surgery is applied to more patients in more cases every day. Comfort is an expected result of nursing care. Assessment of patient comfort is necessary to provide better nursing care.
\end{abstract}

Aim: This study was performed to determine day surgery patients' comfort and factors affecting the patients' comfort.

Material and Methods: Three hundred patients who were admitted to day surgery have been included in this study. For data collection Individual Characteristics Form, Perianesthesia Comfort Scale and State-Trait Anxiety Inventory Form (STAI) were used.

Results: The mean score of comfort $70.197 \pm 11: 01$ mean STAI score of $43.7 \pm 9.03$, trait anxiety scores mean $46.77 \pm 7.51$ were found to be in this study.

Conclusion: Patient's comfort is effected by variables such as the time of giving information about surgery, previous hospital experience. Some of other variables have effect anxiety levels but comfort level has not effected by this variables.

Key Words: Day surgery, patient comfort, nursing. 


\section{Giriş}

Günübirlik cerrahi, sosyal, tıbbi ve cerrahi yönden bu tip cerrahiye uygun hastaların gece yatışı olmaksızın aynı gün içinde ameliyat olarak taburcu oldukları cerrahi girişimlerdir $(1,2,3)$.

Gelişen cerrahi ve anestezi teknikleri ve öz bakımın desteklenmesiyle birlikte tüm dünyada ve ülkemizde günübirlik cerrahi uygulamaları birçok alanda hızla yayılmakta ve giderek artan oranlarda uygulanmaktadır $(1,4,5)$. Günübirlik cerrahi çeşidi ve hasta sayısı her geçen gün artmaktadir.

Konfor, rahatlık ve erinç sözcükleriyle eş anlamlı kullanılır ve üzüntü, sıkıntı, tedirginlik olmama durumu, yorgunluk veya sıkıntı vermeme durumu olarak tanımlanır (6). Hemşirelikte ise fiziksel, psikospritüel, sosyal ve çevresel boyutları olan sorunların üstesinden gelebilme ve huzuru sağlamaya ilişkin çok boyutlu karmaşık bir kavramdır ve hemşirelik bakımının beklenen istendik bir sonucudur $(7,8)$.

Cerrahi girişim uygulanan hastada psikospritüel konforu azaltan en önemli etken kaygıdır. Günübirlik cerrahi girişimlerinden sonra hastalar, yapılan ameliyata özel sorunlar yaşayabilmekle birlikle, genel olarak da birçok sorun yaşayabilmektedirler. Hastanede kalış süresinin kısalığı, günübirlik cerrahi ünitesine ameliyat günü kabul edilme, ameliyat öncesi hazırlıkların evde hastalar tarafından yapılması gibi nedenler, hasta ve yakınlarının ameliyat öncesi ve sonrası uygun bakım ve eğitim almalarında aksaklıkların olmasına ve günübirlik cerrahi sonrası evde bakım aktivitelerini yerine getirirken sorunlar yaşamalarına sebep olmaktadir (9).

Yakın gelecekte günübirlik cerrahi girişimlerin tüm alanlardaki girişimlerin büyük çoğunluğunu oluşturacağı tahmin edilmektedir. Hasta ve ailesinin teşhis ve tedavinin etkilerine ilişkin yaşadıkları sorunlar ile baş etme ve sıkıntıları için konfor sağlamada hemşireler sağlık bakım ekibinin en donanımlı üyeleri olarak kabul edilmektedirler $(7,10,11)$. Hastanın konforu, bakım kalitesi ile ilgili ve bakımın etkinliğiyle ilgili bilgi verir (7). Bu çalışma günübirlik cerrahi hastalarının konfor düzeyini ve etkileyen etmenleri belirlemek üzere yapılmıştır. 
$\mathrm{Bu}$ araştırmanın amacı günübirlik cerrahi hastalarında konfor düzeyini ve hasta konforunu etkileyen etmenleri incelemektir. Araştırmanın soruları şunlardır;

1. Günübirlik cerrahi hastalarında konfor düzeyi nedir?

2. Hastaların konfor düzeyi nelerden etkilenir?

\section{Gereç ve Yöntem}

Araştırma, analitik kesitsel olarak Ağustos 2015-Şubat 2016 tarihleri arasında, Aydın il merkezinde Adnan Menderes Üniversitesi Uygulama ve Araştırma Hastanesi Günübirlik Cerrahi Servisi (Gündüz Hastanesi)'nde yapılmıştır. G Power analiz yöntemiyle etki büyüklügü 2,25; anlamlılık düzeyi $(\alpha)$ 0,05; güç \%80 kabul edilerek örneklem büyüklüğü 269 kişi olarak hesaplanmıştır. 1,2 desen etkisi de göz önüne alınarak 300 hastaya ulaşılmıştır. Örneklem sayısı dışında ayrıca 10 hasta ile ön uygulama yapılmış ve bu kişiler örnekleme katılmamıştır. Araştırmaya 18 yaşından büyük, bilinci açık, iletişim kurabilen ve araştırmaya katılmaya gönüllü hastalar dahil edilmiştir. On sekiz yaşından küçük ve iletişim kurmakta zorlanan hastalar çalışmaya alınmamıştır.

Verilerin toplanmasında; konu ile ilgili literatürden yararlanılarak araştırmacılar tarafından hazırlanan ve sosyodemografik özellikleri içeren Bireysel Özellikler Formu (25 soru), Perianestezi Konfor Ölçeği (25 madde) ve Durumluk - Sürekli Kaygı Ölçeği (40 madde) kullanılmıştır.

Perianestezi Konfor Ölçeği, Katharina Kolcaba tarafından geliştirilmiş, Türk toplumunda güvenilirlik ve geçerlik çalışması 2007 yılında, Hülya Üstündağ ve Fatma Eti Aslan tarafından yapılmıştır (11). Durumluk - Sürekli Kaygı Ölçeği, Spielberg ve arkadaşları tarafından geliştirilmiş, Türkçeye uyarlanması, güvenirlik ve geçerlik çalışmaları Necla Öner ve Ayhan Le Compte (1974-1977) tarafından yapılmıştır (12).

Araştırmanın yapılabilmesi için Adnan Menderes Üniversitesi Uygulama ve Araştırma Hastanesi Başhekimliğinden kurum izni (Tarih:01.07.2015 sayı:63364346/804.01 - 4617) ve Adnan Menderes Üniversitesi Tıp Fakültesi Girişimsel Olmayan Klinik Çalışmalar Etik Kurulundan (Tarih:28.08.2015 sayı:56989545/050.04-316) etik kurul izni alınmıştır. 
Hastaların toplam konfor puanı bağımlı değişkendir. Toplam konfor puanı dışında kalan yaş, medeni durum, eğitim durumu, çocuk sahibi olma, evde refakat edecek birinin varlı̆ğ, kronik hastalık varlığı, hastane deneyimi, ameliyat deneyimi, ameliyat hakkında bilgilendirme gibi özellikler ve toplam durumluk ve toplam süreklilik puanlarının tamamı bağımsız değişkenlerdir.

\section{Verilerin analizi}

Araştırmada elde edilen veriler SPSS (Statistical Package for Social Sciences) for Windows 22.0 programı kullanılarak analiz edilmiştir. Verilerin değerlendirilmesinde tanımlayıcı istatistiksel yöntem olarak sayı, yüzde, aritmetik ortalama, standart sapma kullanılmıştır. Verilerin karşılaştırılmasında Mann Whitney-U testi ve Kruskall Wallis testi kullanılmıştır. $\mathrm{Bu}$ testler sonrasında gruplar arasındaki farklılı̆̆ın hangi gruptan kaynaklandığını belirlemek üzere Bonferroni Düzeltmeli Mann Whitney U testi, değişkenler arasında ilişkiyi belirlemek için Spearman korelasyon analizi kullanılmıştır. Toplam konfor puanını etkileyen değişkenleri belirlemek için çoklu regresyon analizi uygulanmıştır. Bulgular \%95 güven aralığında, \%5 anlamlılık düzeyinde değerlendirilmiştir. Ölçülen değişkenlerin normal dağılım gösterip göstermediğine bakıldığında Kolmogorov-Smirnov testi sonuçlarına göre (n>30) yaş, konfor ölçeği puanı, durumluk ve sürekli kaygı ölçeği puanları verilerinin normal dağılıma uymadığı görülmüştür.

\section{Bulgular}

Araştırmaya alınan toplam 300 hastanın verileri analiz edilmiştir.

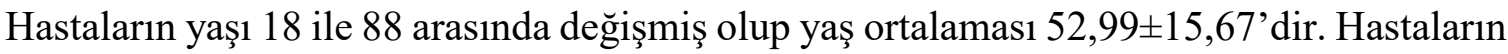
\%27,0 si 56-65 yaş aralığındadır. Araştırmaya katılan hastaların \%57,7'si kadındır. Hastalardan \% 47,9'u lise mezunu, \%80'ini evli ve \%86,7'si çocuk sahibidir. Hastaların \%73,3'ü eşiyle birlikte \%9,7'si yalnız yaşamaktadır. Hastaların \%40'1 ev hanımıdır ve \%45,7'si ilçede yaşamaktadır. Hastaların \%87,7'sinin hastalık durumunda evde kendisine yardımcı olabilecek bir yakınının olduğu ve bunlardan \%74,5'inin evde yardımcı olabilecek kişiye eş olarak yanıt verdiği görülmüştür. Hastaların \%52,7'sinin kronik hastalığı olduğu, \%46,2'sinin hipertansiyon tanıs1 aldığı görülmüştür. Hastaların hastane deneyimi \%80,3'tür ve bunların da \%86,3'ünün aynı zamanda ameliyat deneyimi olduğunu bildirmiştir. Şimdiki ameliyatıyla aynı tür ameliyat deneyimi olanların oranı \%37,0'dir. Hastaların \%91,7'si günübirlik cerrahi hakkında 
bilgilendirilmiş ve $\% 54,5^{\prime} \mathrm{i}$ hastaneye ilk başvurduğunda bilgilendirildiğini iletmiştir. Hastaların \%45'ine göre günübirlik cerrahi ile ilgili yapılan bilgilendirme yeterlidir. Hastaların bu bilgilendirmede eksik buldukları konuların başında ameliyat sonrası yaşanabilecek sorunlar $(\% 34,7)$ ve ameliyat sonrası evde yaşanabilecek sorunlar $(\% 32,0)$ gelmektedir.

Hastaların konfor ve kaygıyı etkileyebileceği düşünülen bireysel özelliklerine bakıldığında; en yüksek sürekli kaygı puanına sahip yaş grubunun 50,26 $\pm 7,69$ puanla 75 yaş

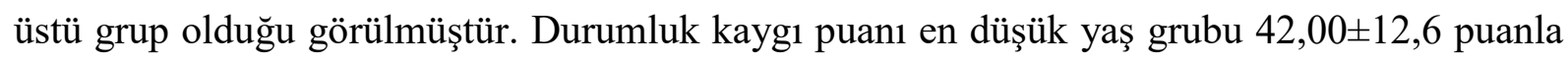
26-35 yaş arası gruptur. Yaş grupları arası ölçek puanlarına bakıldığında yaşla birlikte genel olarak sürekli kaygı puanının arttığı ve gruplar arası farklılığın anlamlı olduğu saptanmıştır. $(\mathrm{KW}=16,948 ; \mathrm{p}=0,009<0.05)$. Araştırmaya katılan hastaların konfor puanları ve durumluk kaygı puanları ortalamalarının yaş değişkeni açısından anlamlı bir farklılık gösterip göstermediğini belirlemek amacıyla yapılan Kruskal Wallis H-Testi sonuçlarına göre; grup ortalamaları arasındaki farkın anlamlı olmadığı görülmüştür ( $p>0.05)$ (Tablo 1).

Kadınların ortalama durumluk kaygı puanları $(45,27 \pm 8,67)$, erkeklerin ortalama durumluk kaygı puanlarından $(41,70 \pm 9,14)$ yüksek olduğu ve aradaki farkın istatiksel olarak anlamlı olduğu görülmüştür $(U=8$ 05,000; $\mathrm{p}=0,000<0,05)$ (Tablo 1).

Kadınların sürekli kaygı puanları ortalaması $(47,89)$, erkeklerin sürekli kaygı puanları ortalamasından $(45,26)$ yüksektir ve bu fark istatistiksel açıdan anlamlıdır ( $U=8$ 450,000; $\mathrm{p}=0,001<0,05)$. Cinsiyetlere göre konfor puanı ortalamalarına bakıldığında erkeklerin konfor puanı ortalamasının $(70,66 \pm 10,54)$ kadınların konfor puanı ortalamasından $(69,85 \pm 11,36)$ yüksek olduğu ancak farkın anlamlı olmadığı görülmüştür ( $p>0,05)$ (Tablo 1).

Medeni durum değişkenine göre durumluk kaygı puanı ortalaması evli bireylerde $43,81 \pm 9,00$ ve bekar bireylerde 43,55 $\pm 9,25$ olup fark anlamlı değildir. Sürekli kaygı puan

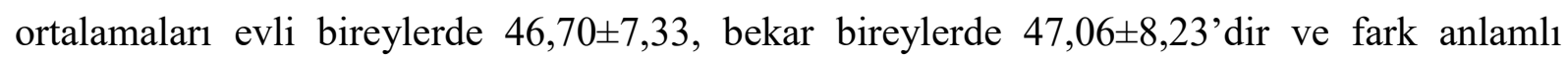

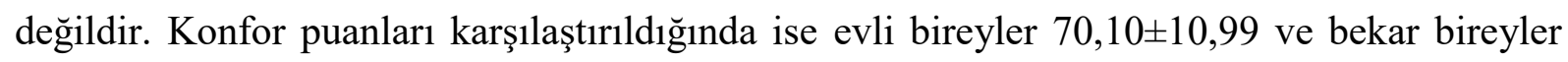
$70,55 \pm 11,17$ ortalamaya sahip olup fark anlamlı değildir ( $>00,05)$ (Tablo 1).

Kronik hastalığı olanların sürekli kaygı puan ortalamasının $(48,69 \pm 7,09)$ kronik hastalığı olmayanların sürekli kayg1 puan ortalamasından $(44,64 \pm 7,41)$ daha yüksek olduğu görülmüştür. Gruplar arasındaki fark istatiksel olarak anlamlıdır $(U=7649,000 ; p=0,000<0,05)$. 
Konfor ve durumluk kaygı puanları ortalamalarının kronik hastalık varlığına göre anlamlı bir farkl1l1k göstermediği görülmüştür ( $\mathrm{p}>0,05)$ (Tablo1).

Tablo 1. Hastaların Sosyodemografik Özellikleri ile Konfor, Durumluk Kaygı ve Sürekli Kaygı Puan Ortalamalarının Karşılaştırılması

\begin{tabular}{|c|c|c|c|c|c|c|c|}
\hline Özellikler & $\mathbf{n}$ & $\begin{array}{l}\text { Konfor } \\
\mathrm{X} \pm \mathrm{SS}\end{array}$ & $\begin{array}{l}\mathrm{U} / \mathbf{K W} \\
\mathrm{p}\end{array}$ & $\begin{array}{l}\text { Durumluk Kaygı } \\
\mathrm{X} \pm \mathrm{SS}\end{array}$ & $\begin{array}{l}\mathrm{U} / \mathrm{KW} \\
\mathrm{p}\end{array}$ & $\begin{array}{ll}\text { Sürekli } & \text { Kayg } \\
X \pm \text { SS } & \\
\end{array}$ & $\begin{array}{l}\mathbf{U} / \mathbf{K W} \\
\mathrm{p}\end{array}$ \\
\hline \multicolumn{8}{|c|}{ 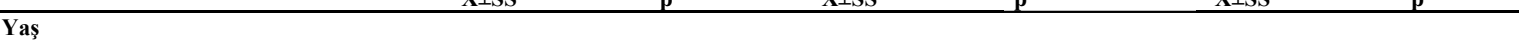 } \\
\hline - $18-25$ Yaş & 19 & $68,84 \pm 11,90$ & $10,213^{* *}$ & $43,05 \pm 7,85$ & $3,490 * *$ & $46,89 \pm 5,89$ & $16,948 * *$ \\
\hline - $26-35$ Yaş & 32 & $65,46 \pm 10,43$ & 0,116 & $42,00 \pm 12,66$ & 0,745 & $43,12 \pm 7,93$ & 0,009 \\
\hline - $36-45$ Yaş & 41 & $68,56 \pm 10,13$ & & $42,39 \pm 9,03$ & & $45,68 \pm 9,70$ & \\
\hline - $46-55$ Yaş & 59 & $71,54 \pm 9,37$ & & $44,69 \pm 9,42$ & & $45,23 \pm 6,38$ & \\
\hline - 56-65 Yas & 81 & $72,23 \pm 10,65$ & & $43,60 \pm 8,68$ & & $47,86 \pm 6,53$ & \\
\hline • 56-65 Yaş & 49 & $70,38 \pm 12,67$ & & $45,36 \pm 6,77$ & & $48,73 \pm 7,29$ & \\
\hline $\begin{array}{l}\text { - } \quad 66-75 \text { Yaş } \\
\text { - } 75 \text { Yas üstü }\end{array}$ & 19 & $69,68 \pm 12,94$ & & $44,00 \pm 8,56$ & & $50,26 \pm 7,69$ & \\
\hline \multicolumn{8}{|l|}{ Cinsiyet 75 Yaş üstü } \\
\hline - Kadın & 173 & $69,85 \pm 11,36$ & $10903,000 *$ & $45,27 \pm 8,67$ & $8305,000 *$ & $47,89 \pm 8,04$ & 8450,000 \\
\hline - Erkek & 127 & $70,66 \pm 10,54$ & 0,911 & $41,70 \pm 9,14$ & 0,000 & $45,26 \pm 6,45$ & 0,001 \\
\hline \multicolumn{8}{|l|}{ Medeni durum } \\
\hline - Evli & 240 & $70,10 \pm 10,99$ & $7044,000^{*}$ & $43,81 \pm 9,00$ & $7074,500 *$ & $46,70 \pm 7,33$ & $6968,500^{*}$ \\
\hline - Bekar & 60 & $70,55 \pm 11,17$ & 0,795 & $43,55 \pm 9,25$ & 0,834 & $47,06 \pm 8,23$ & 0,700 \\
\hline \multicolumn{8}{|l|}{ Sosyal güvence } \\
\hline - Var & 286 & $70,29 \pm 11,06$ & $1824,000^{*}$ & $43,75 \pm 9,03$ & $1939,500 *$ & $46,75 \pm 7,62$ & $1939,500 *$ \\
\hline - Yok & 14 & $68,28 \pm 9,95$ & 0,574 & $43,78 \pm 9,44$ & 0,843 & $47,21 \pm 4,87$ & 0,843 \\
\hline \multicolumn{8}{|l|}{ Eğitim durumu } \\
\hline - Okur yazar & 19 & $70,15 \pm 12,73$ & $7,367^{* *}$ & $44,63 \pm 8,19$ & $11,470^{* * *}$ & $48,79 \pm 7,45$ & $32,092 * *$ \\
\hline - Okur yazar değil & 16 & $73,93 \pm 13,69$ & 0,195 & $49,18 \pm 5,45$ & 0,043 & $54,12 \pm 8,29$ & 0,000 \\
\hline - İlkokul & 149 & $69,83 \pm 10,90$ & & $43,15 \pm 8,67$ & & $47,80 \pm 7,19$ & \\
\hline - Ortaokul & 16 & $71,25 \pm 11,80$ & & $40,50 \pm 8,09$ & & $45,31 \pm 7,88$ & \\
\hline - Lise & 50 & $67,96 \pm 9,84$ & & $43,58 \pm 10,01$ & & $44,06 \pm 5,36$ & \\
\hline - Yüksekokul-fakülte & 50 & $71,98 \pm 10,50$ & & $44,72 \pm 10,09$ & & $43,78 \pm 7,67$ & \\
\hline \multicolumn{8}{|l|}{ Kronik hastalık varlığı } \\
\hline - Var & 158 & $70,96 \pm 10,80$ & $10132,500 *$ & $44,67 \pm 7,64$ & 10210,500 & $48,69 \pm 7,09$ & 7649,000 \\
\hline - Yok & 142 & $69,34 \pm 11,21$ & 0,148 & $42,74 \pm 10,30$ & 0,179 & $44,64 \pm 7,41$ & 0,000 \\
\hline
\end{tabular}

*Mann-Whitney U $\quad$ **Kruskal-Wallis

Hastaların günübirlik cerrahi sürecinde aldıkları bakımdan memnuniyet oranı \%72'dir. Hastaların bu süreçte memnuniyetini olumsuz etkileyen faktörlerin başında \%45,1 oranında ameliyat öncesi çok beklemek yer almıştır.

Hastaların konfor, durumluk kaygı ve sürekli kaygı düzeylerine bakıldığında; ortalama konfor puanı $70,19 \pm 11,01$, ortalama durumluk kaygı puanı 43,76 $\pm 9,03$ ve ortalama sürekli

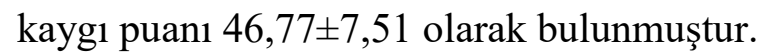

Durumluk kaygı ve sürekli kaygı ile konfor arasındaki ilişki belirlemek üzere yapılan regresyon analizi sonucunda durumluk kaygı puanının konfor üzerine etkisi istatistiksel olarak anlamlı bulunmuştur $(\mathrm{F}=11,971 ; \mathrm{p}=0,000<0.05)$. Konfor düzeyinin belirleyicisi olarak durumluk kaygı, sürekli kaygı değişkenleri ile ilişkisinin (açıklayıcılık gücünün) zayıf olduğu 
görülmüştür $(\mathrm{R} 2=0,068)$. Hastaların durumluk kayg1 düzeyi konfor düzeyini arttırdığ1 görülmüştür $(\beta=0,321)$. Hastaların sürekli kaygı düzeyinin konfor düzeyini etkilemediği görülmüştür $(\mathrm{p}=0.682>0.05)$

Konfor puanları ortalamaları daha önce hastanede yatmış hastalarda $(70,77 \pm 11,13)$, daha önce hastanede yatmamış olanlardan $(67,84 \pm 10,24)$ yüksek bulunmuştur. Bu fark istatiksel olarak anlamlıdır $(U=5$ 804,000; $p=0,029<0,05)$. Hastane deneyimi olan hastaların sürekli kayg1 puanları ortalamaları $(47,34 \pm 7,59)$ hastane deneyimi olmayanların sürekli kaygı puan ortalamasından $(44,44 \pm 6,73)$ anlamlı olarak daha yüksek bulunmuştur ( $U=5$ 433,000; $\mathrm{p}=0,005<0,05)$. Hastane deneyimi olanlarla olmayanların durumluk kaygı puanları arasında anlamlı farklılık olmadığı görülmüştür ( $>00,05$ ) (Tablo 2).

Daha önceden ameliyat deneyimi olan hastalar ile ameliyat deneyimi olmayan hastaların konfor, durumluk kaygı ve sürekli kaygı puan ortalamaları arasındaki farkın anlamlı olmadığı görülmüştür $(\mathrm{p}>0,05)$. Ayrıca ameliyat deneyimi olan hastalardan daha önce aynı sebeple ameliyat olanlarla farklı türde bir ameliyat geçirenlerin puan ortalamaları arasında da anlamlı fark olmadığı görülmüştür (Tablo 2).

Evde hastalık halinde kendisine yardım edecek birisi olan hastaların sürekli kaygı puan ortalamaları $(46,24 \pm 7,25)$ evde yardım edecek biri olmayanların sürekli kaygı puan ortalamalarından $(50,56 \pm 8,30)$ düşük bulunmuştur. Fark istatistiksel açıdan anlamlıdır ( $U=3$ 220,500; $\mathrm{p}=0,001<0,05)$. Konfor, durumluk kaygı puan ortalamaları arasındaki farkın ise istatistiksel açıdan anlamlı olmadığı görülmüştür. Önceden günübirlik cerrahi hakkında bilgilendirilen ve bilgilendirilmeyen hastaların konfor, durumluk kaygı, sürekli kaygı puanları ortalamaları arasında anlamlı fark bulunmamıştır $(\mathrm{p}>0,05)$ (Tablo 2). 
Tablo 2. Hastaların Kaygı ve Konfor Düzeylerini Etkileyebileceği Düşünülen Özelliklere Göre Karşılaştırılması

\begin{tabular}{|c|c|c|c|c|c|c|c|}
\hline zellikler & $\mathbf{n}$ & $\begin{array}{l}\text { Konfor } \\
\mathrm{X} \pm \mathrm{SS}\end{array}$ & $\begin{array}{l}\mathbf{U} \\
\mathbf{K W} \\
\mathbf{p}\end{array}$ & $\begin{array}{l}\text { Durumluk } \\
\text { Kaygı } \\
\mathrm{X} \pm \mathbf{S S}\end{array}$ & $\begin{array}{l}\mathrm{U} \\
\mathbf{K W} \\
\mathbf{p}\end{array}$ & $\begin{array}{l}\text { Sürekli } \\
\text { Kaygı } \\
\text { X } \pm \text { SS }\end{array}$ & $\begin{array}{l}\mathbf{U} \\
\mathbf{K W} \\
\mathbf{p}\end{array}$ \\
\hline \multicolumn{8}{|c|}{ astane deneyimi } \\
\hline $\begin{array}{ll}\text { - } & \text { Var } \\
- & \text { Yok }\end{array}$ & $\begin{array}{l}241 \\
59\end{array}$ & $\begin{array}{l}70,77 \pm 11,13 \\
67,84 \pm 10,24\end{array}$ & $\begin{array}{l}5804,000^{*} \\
\mathbf{0 , 0 2 9}\end{array}$ & $\begin{array}{l}43,88 \pm 9,12 \\
43,25 \pm 8,74\end{array}$ & $\begin{array}{l}6856,000^{*} \\
0,671\end{array}$ & $\begin{array}{l}47,34 \pm 7,59 \\
44,44 \pm 6,73\end{array}$ & $\begin{array}{l}5433,000^{*} \\
\mathbf{0 , 0 0 5}\end{array}$ \\
\hline \multicolumn{8}{|c|}{ neliyat deneyimi } \\
\hline $\begin{array}{ll}\text { - } & \text { Var } \\
\text { - } & \text { Yok }\end{array}$ & $\begin{array}{l}208 \\
33\end{array}$ & $\begin{array}{l}70,96 \pm 11,04 \\
69,57 \pm 11,80\end{array}$ & $\begin{array}{l}3202,500^{*} \\
0,537\end{array}$ & $\begin{array}{l}43,78 \pm 9,08 \\
44,51 \pm 9,45\end{array}$ & $\begin{array}{l}3058,500^{*} \\
0,315\end{array}$ & $\begin{array}{l}47,48 \pm 7,20 \\
46,51 \pm 9,81\end{array}$ & $\begin{array}{l}3057,000 * \\
0,313\end{array}$ \\
\hline $\begin{array}{l}\text { nnı am } \\
\text { neyimi }\end{array}$ & & & & & & & \\
\hline $\begin{array}{ll}- & \text { Var } \\
- & \text { Yok }\end{array}$ & $\begin{array}{l}77 \\
164\end{array}$ & $\begin{array}{l}70,54 \pm 11,26 \\
70,87 \pm 11,11\end{array}$ & $\begin{array}{l}6176,000^{*} \\
0,784\end{array}$ & $\begin{array}{l}43,26 \pm 7,99 \\
44,17 \pm 9,61\end{array}$ & $\begin{array}{l}5532,000^{*} \\
0,121\end{array}$ & $\begin{array}{l}47,20 \pm 7,12 \\
47,41 \pm 7,82\end{array}$ & $\begin{array}{l}6227,000 * \\
0,863\end{array}$ \\
\hline \multicolumn{8}{|c|}{$\begin{array}{l}\text { Irklı ameliyat } \\
\text { neyimi }\end{array}$} \\
\hline $\begin{array}{ll}- & \text { Var } \\
- & \text { Yok }\end{array}$ & $\begin{array}{l}160 \\
81\end{array}$ & $\begin{array}{l}71,10 \pm 11,03 \\
70,11 \pm 11,38\end{array}$ & $\begin{array}{l}6389,000^{*} \\
0,859\end{array}$ & $\begin{array}{l}43,87 \pm 9,40 \\
43,90 \pm 8,59\end{array}$ & $\begin{array}{l}6459,500^{*} \\
0,968\end{array}$ & $\begin{array}{l}47,61 \pm 7,30 \\
46,82 \pm 8,16\end{array}$ & $\begin{array}{l}6105,000 * \\
0,463\end{array}$ \\
\hline \multicolumn{8}{|l|}{ ycuk } \\
\hline $\begin{array}{ll}- & \text { Var } \\
- & \text { Yok }\end{array}$ & $\begin{array}{l}260 \\
40\end{array}$ & $\begin{array}{l}70,55 \pm 10,83 \\
67,90 \pm 11,96\end{array}$ & $\begin{array}{l}4477,500^{*} \\
0,157\end{array}$ & $\begin{array}{l}43,90 \pm 8,77 \\
42,80 \pm 10,69\end{array}$ & $\begin{array}{l}4669,500^{*} \\
0,298\end{array}$ & $\begin{array}{l}47,11 \pm 7,60 \\
44,57 \pm 6,59\end{array}$ & $\begin{array}{l}4277,500 * \\
0,071\end{array}$ \\
\hline \multicolumn{8}{|c|}{$\begin{array}{l}\text { de yardım } \\
\text { ecek biri }\end{array}$} \\
\hline $\begin{array}{ll}\text { - } & \text { Var } \\
\text { - } & \text { Yok }\end{array}$ & $\begin{array}{l}263 \\
37\end{array}$ & $\begin{array}{l}70,14 \pm 11,07 \\
70,54 \pm 10,67\end{array}$ & $\begin{array}{l}4477,500^{*} \\
0,157\end{array}$ & $\begin{array}{l}43,50 \pm 9,12 \\
45,56 \pm 8,30\end{array}$ & $\begin{array}{l}4179,000^{*} \\
0,164\end{array}$ & $\begin{array}{l}46,24 \pm 7,25 \\
50,56 \pm 8,30\end{array}$ & $\begin{array}{l}3220,500 * \\
\mathbf{0 , 0 0 1}\end{array}$ \\
\hline
\end{tabular}

Günübirlik cerrahi hakkında bilgilendirmeyi yeterli bulmayanların durumluk kaygı puan ortalamaları $(46,45 \pm 10,14)$, bilgilendirmeyi yeterli bulanların durumluk kaygı puan ortalamalarından $(41,24 \pm 9,28)$ yüksek bulunmuştur. Ayrıca bilgilendirmeyi yeterli bulma kısmen olanların durumluk kaygı puanları $(45,72 \pm 7,97)$, bilgilendirmeyi yeterli bulanların durumluk kaygı puanlarından $(41,24 \pm 9,28)$ yüksek bulunmuştur gruplar arası fark istatiksel olarak anlamlıdır $(\mathrm{KW}=16,779 ; \mathrm{p}=0,001<0.05)$. Bilgilendirmeyi yeterli bulmayanların sürekli kayg1 puanları $(47,83 \pm 7,62)$, bilgilendirmeyi yeterli bulanların sürekli kayg1 puanlarından $(45,14 \pm 8,01)$ yüksek bulunmuştur. Bilgilendirmeyi kısmen yeterli bulanların sürekli kaygı puanları $(48,14 \pm 6,21)$, bilgilendirmeyi yeterli bulanların sürekli kaygı puanlarından $(45,14 \pm 8,01)$ yüksek bulunmuştur ve gruplar arası farklılık anlamlıdır $(\mathrm{KW}=15,839$; $\mathrm{p}=0,001<0.05)($ Tablo 3). 
Tablo 3. Ameliyat Hakkında Bilgilendirme İle Konfor, Durumluk Kaygı ve Sürekli Kayg1 Arasındaki İlişki

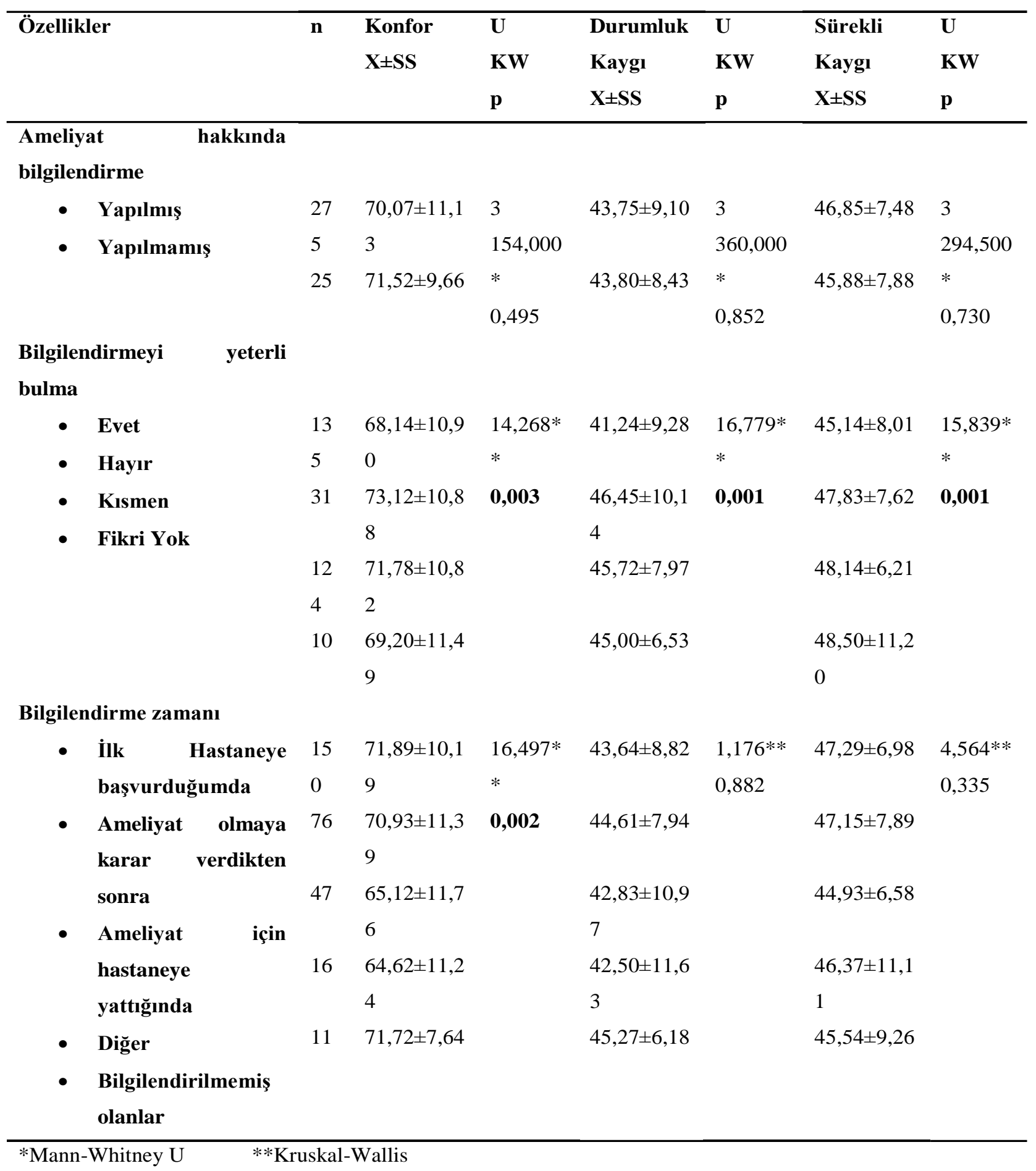


Bilgilendirme zamanına göre ölçek puanlarına bakıldığında konfor puanı en yüksek grubun günübirlik cerrahi hakkında bilgilendirmesi ilk hastaneye başvurduğunda yapılan hastalar olduğu görülmüştür. Grupların bilgilendirme zamanı konfor puan ortalamaları karşılaştırıldığında gruplar arası farkın anlamlı olduğu görülmüştür (KW=16,497; $\mathrm{p}=0,002<0.05)$. Araştırmaya katılan hastaların durumluk kaygı ve sürekli kaygı puan ortalamalarının bilgilendirme zamanı değişkeni açısından anlamlı farklılık göstermediği görülmüştür ( $\mathrm{p}>0.05)$ (Tablo 3).

\section{Tartışma}

Günübirlik cerrahide hasta konforunu ve etkileyen etmenleri belirlemek amacıyla yapılan bu çalışmadan elde edilen bulgular literatür bilgisi doğrultusunda ele alınarak tartışılmıştır.

Araştırmamızda hastaların kaygı düzeyinin yüksek olduğu sonucuna ulaşılmıştır. Fındık ve Yıldızeli Topçu (2012)'nun cerrahi işleme alınış şeklinin hasta kaygısı üzerine etkisini araştırmak üzere yaptıkları çalışmada günübirlik cerrahi hastalarının ve acil cerrahi hastalarının kaygı düzeyinin diğer planlı cerrahilere göre daha yüksek olduğu sonucuna ulaşmışlardır. Çalışma sonuçlarımızla bu veriyi desteklemektedir. Yine aynı çalışmaya göre örneklemin \%54,5'inin kadın olduğu bildirilmiştir ve bu çalışmada \%57,7 olan kadın cinsiyet oranı bu çalışmayla benzerlik göstermektedir. Her iki araştırmada da kadın cinsiyetle kaygı düzeyleri arasında pozitif yönlü anlamlı ilişki saptanmıştır. Kaygı düzeyini yorumlamada cinsiyet faktörünün kaygı düzeyini etkileyebileceğinin göz önünde bulundurulması gerektiği düşünülmektedir. Okanlı ve arkadaşlarının (2005) cerrahi kliniklerde yatan hastalarda kaygı ve depresyon düzeyini belirlemeye yönelik yaptıkları araştırma sonuçlarına göre kadın hastaların erkek hastalara göre daha fazla kaygı yaşadığını belirlemişlerdir. Bizim araştırmamızda da kadın hastaların hem durumluk kaygı puan ortalamaları hem de sürekli kaygı puan ortalamaları erkek hastaların ortalama durumluk ve ortalama sürekli kaygı puan ortalamalarına göre daha yüksek bulunmuştur ve gruplar arasındaki farklılık her iki puan ortalamalarında istatiksel olarak anlamlidir.

Araştırmaya katılan hastaların ameliyat öncesi durumluk kaygı puan ortalamalarıyla ameliyat sonu konfor puanı ortalamaları karşılaştırıldığında bu iki bulgu arasında zayıf da olsa pozitif yönlü anlamlı ilişki olduğu saptanmıştır. Yani ameliyat öncesi durumluk kaygı puanı 
ortalaması arttıkça ameliyat sonrası konfor puanı ortalaması da artmaktadır. Ameliyat öncesi bekleyen hastalarda, ameliyat sonrası ağrı yaşanacağı düşüncesi, ameliyat sırasına ilişkin düşünceler, ameliyat için beklemek, beklerken dişardan garip göründüğünü düşünmek, damar yolu açılması gibi bazı durumlar ameliyat öncesi dönemde kişilerde kaygıya sebep olabilmektedir (14). Bu araştırmada da ameliyat öncesi durumluk kaygı puanının yüksekliğinin bu sebeplerden kaynaklandığg düşünülmektedir. Durumluk kaygı puanı yüksek olan hastaların ameliyat sonrası konfor puanlarının yüksek çıkması ise konfor kuramının rahatlama boyutuyla ilişkisi olduğu düşünülebilir. Rahatlık tanımına bakıldığında ferahlama, gevşeme, kaçınılmaz olan rahatsızlık durumuyla baş etme, üstesinden gelme yeteneğine sahip olma ifadelerinin konforu tanımlamada kullanılan ifadeler olduğu görülür (15). Günübirlik cerrahi hastalarının ameliyat sonrası dönemde diğer cerrahi hastalarına göre daha az fiziksel yakınmasının olması, minimal invaziv girişim, kısa anestezi süresi, ve kısa işlem süresi gibi fiziksel olumlu faktörlerin ve rahatsızlık durumuyla baş etmiş olma, erken mobilize olabilecek olma, birkaç saat içinde hastaneden çıkıp eve gidebileceğini bilme gibi çevresel ve psikospritüel olumlu faktörlerin ameliyat öncesinde kaygıları yüksek olsa bile ameliyat sonrası dönemde hastaların konforunu arttırmış olabileceği düşünülmektedir.

Günübirlik cerrahi hastalarında rahatsızlık oluşturabilecek durumlar arasında bilgi eksikliği veya ameliyat hakkında yetersiz bilgilendirmenin olduğu ve hastaların konforunu olumsuz yönde etkileyebileceği öne sürülmüştür (17). Araştırmamızın sonuçlarına göre kendilerine günübirlik cerrahi işlem hakkında yapılan bilgilendirmeyi yetersiz bulan hastaların durumluk kaygı puan ortalaması yapılan bilgilendirmeyi yeterli bulan hastaların durumluk kayg1 puanı ortalamasından ve yapılan bilgilendirmeyi kısmen yeterli bulan hastaların durumluk kaygı puan ortalamasından daha yüksek bulunmuştur ve gruplar arasındaki fark istatistiksel olarak anlamlıdır. Araştırmamızın bulguları Rosen ve arkadaşlarının verisini desteklemektedir.

Araştırmamızda hastaneye ilk başvurduğunda bilgilendirilen hastaların konfor puanları ortalaması, ameliyat olmaya karar verdikten sonra bilgilendirilenden, ameliyat için hastaneye yattığında bilgilendirilenlerden ve diğer zamanlarda bilgilendirilenlerden daha yüksek çıkmıştır ve gruplar arasındaki farklılık anlamlıdır. Cerrahi girişime ihtiyaç olduğunun hastaya söylenmesi ile başlayan kaygı hastaneye yatmayla birlikte artar ve hastanın hastalığa uyumunu, bakımını, yaşam kalitesini, tedavi süresini ve masraflarını, düzelme ve iyilik halini, hastalığın 
gidişini ve hastanın ek hastalıklarla karşılaşmasını olumsuz yönde etkileyebilir (13). Hastaların bilgilendirilme zamanı ile ameliyat tarihi arasında geçen sürenin uzunluğu hastaların kaygı ile başetmesi ve uyum sağlaması açısından olumlu etki ederek hasta konforunu yükselttiği düşünülmektedir. Gürçayır 2011'de kalça protezi yapılan hastalarla yaptı̆̆g konfor çalışmasında ameliyattan önce verilen eğitimin hasta konforu üzerinde olumlu etki ettiğini bulmuştur. Aynı şekilde bizim araştırmamızda da günübirlik cerrahi hastalarında da eğitimin önceden yapılmasının hasta konforunu olumlu etkilediği düşünülmektedir.

Araştırmamızda günübirlik cerrahi hakkında bilgilendirme yapılmış ve yapılmamış olan hastaların konfor ve kaygı düzeylerinin gruplar arasında farklılık oluşturmadığı görülmüştür. Cerrahi hastalarında yapılmış ve kaygı düzeyini değerlendiren cerrahi hastalarında yapılan çalışmalarda önceden bilgilendirme yapılan hastaların durumluk kaygısının daha düşük olduğu görülmüştür (19). Ayrıca günübirlik cerrahi hastalarında bilgi eksikliği ve ameliyata ilişkin bilginin yetersizliğinin hasta konforunda bozulmaya yol açabilecek etkenler olduğu bildirilmiştir (17). Çalışmamızın bulguları bu verilerle benzer değildir. Bu durumun hastalar günübirlik cerrahi ile yapılacak işlem hakkında bilgi sahibi olmasalar bile işlemin kısa süreceğini düşünmelerinin durumluk kaygılarında artışa sebep olmamasından kaynaklandığı düşünülebilir.

Araştırmamızda günübirlik işlem hakkında kendisine önceden bilgilendirme yapılmadığını ifade eden hastaların konfor, durumluk kaygı ve sürekli kaygı puan ortalamaları arasında anlamlı farklılık görülmemiştir. Yapılan çalışmalarda ameliyat öncesi ve sonrasında karşılaşılacak durumlarla ilgili bilgi eksikliğinin cerrahi hastalarında kaygı düzeyini arttırdığı ve sonrasında hasta konforunu olumsuz yönde etkileyebilecek bulant1, kusma, ağrı gibi şikayetlerin artmasına sebep olabileceği, bilgilendirme yapılmasının hastaların ameliyat öncesi kaygılarını azaltabileceği belirtilmiştir (13). Araştırmamızın sonuçları bu veriyi desteklememektedir.

Hastalara ameliyat öncesi verilen bilginin yetersiz oluşu hastada kaygı düzeyini arttırabilmektedir. $\mathrm{Bu}$ araştırmada bilgilendirme yapılan hastalar arasında bilgilendirmeyi yeterli bulmayanların hem durumluk kaygı puanı ortalaması, hem de sürekli ve kısmen yeterli bulanların hem durumluk hem de sürekli kaygı puanlarının, bilgilendirmeyi yeterli bulan gruptan daha yüksek olduğu görülmüştür. Bu sonuç bilgilendirme yetersizliğinin kaygıyı arttırdığını ortaya koyan araştırmalarla ve literatür bilgisiyle benzerdir (19). 
Araştırmamızda yaş değişkeninin kaygı puan ortalamaları üzerinde farklılık oluşturduğu ancak konfor puan ortalamaları arasında farklılık oluşturmadığı görülmüştür. Gruplar arası ölçek puanlarına bakıldığında yaşla birlikte genel olarak sürekli kaygı puanının arttığı ve gruplar arası farklılığın anlamlı olduğu saptanmıştır. Yaş arttıkça kronik hastalıklar ve kaygıya yatkınlık artmaktadır. Kaygı puanının artması literatür bilgisiyle ve daha önceden yapılan kaygı düzeyini ve etkileyen faktörleri belirlemek amacıyla yapılan çalışmalarla uyumludur (11).

Araştırmamızda daha önce hastanede yatmış olan hastaların konfor puanları ortalaması, daha önce hastanede yatmamış olanların konfor puanları ortalamasından anlamlı olarak yüksek bulunmuştur. Önceden hastanede yatmış olma yapılacak işlemleri ve verilen bilgileri daha iyi anlamayı sağladığı, içinde bulunulan durumu kabullenmeyi ve çevreye uyum sağlamayı kolaylaştırdığı için hasta konforunu olumlu yönde etkilediği düşünülmektedir. Hastane deneyimi olan hastaların sürekli kaygı puanları ortalamaları hastane deneyimi olmayanların sürekli kaygı puan ortalamasından anlamlı olarak daha yüksek bulunmuştur. Hastane deneyimi olanlarla olmayanların durumluk kaygı puanları arasında istatiksel olarak farklılık olmadığı görülmüştür ( $\mathrm{p}>0,05)$. Bu durumun (sürekli ve durumluk kaygı sonuçlarının farklı olması) hastane deneyimi olan bireylerin daha yaşlı olmasından ve hastane deneyimi olan hastalar arasında kronik hastalı̆̆ düşünülmektedir. Hastaların aynı veya farklı ameliyat deneyimi olmasını kaygı ve konfor puanları arasında anlamlı farklılığa yol açmadığı görülmüştür. Akkaş Gürsoy'un (2001)'de orta büyüklükte ve minör cerrahi geçirecek hastaların kaygı düzeylerini incelediği çalışmasında daha önceden ameliyat deneyimi olmayan hastaların durumluk kaygı puanlarının önceden ameliyat deneyimi olan hastalardan daha fazla olduğunu bildirmiştir. Çalışmamızın sonuçlarındaki farklılığın günübirlik cerrahi hastalarının yapılacak işlemler ve hastanede kalış süresini kısa oluşu sebebiyle hastaların daha az anlık kaygı yaşamış olabilecekleri düşünülmektedir.

Sonuç olarak;

$\mathrm{Bu}$ çalışmada hasta konforunun yapılacak cerrahi ile ilgili bilgi verilme zamanı, daha önceden hastane deneyimi bulunma gibi değişkenlere göre farklılık gösterdiği, hastaların yaş, kronik hastalık varlığı, eğitim durumu gibi değişkenlere göre kaygı puanlarının farklılık gösterdiği ancak konfor puan ortalamalarının farklılık göstermediği sonucuna ulaşılmıştır. Günübirlik cerrahi hastalarında hasta konforu ve hasta konforunu etkileyen faktörlerin konforu 
etkileyebilecek fiziksel faktörler de değerlendirilecek şekilde daha ayrıntılı araştırmaların yapılması ve hemşirelik hizmetlerinin bir çıtısı olan hasta konforunun günübirlik cerrahi hastalarında sürekli değerlendirilmesi ve hasta konforunu yükseltecek ve kaygı düzeyini düşürecek önlemlerin alınması önerilir.

\section{Kaynaklar}

1. Aksoy G, Sayın, YY. Günübirlik cerrahide hastanın hazırlığı. CÜ Hemşirelik Yüksek Okulu Dergisi 2004;8(2):39-46.

2. Verna R, Alladi R, Jackson I, et al. Day case and short stay surgery:2, Anaesthesia 2011;66:417-434.

3. Lemos P, Jarrett P, Philip B eds. Day Surgery Development and Practice. Porto: International Association for Ambulatory Surgery, 2006.

4. Terzi C, Okman U, Eryılmaz M. Türkiye'de genel cerrahi insan gücü işgücü ve iş yükü raporu, Türk Cerrahi Derneği, Ankara 2009, ss: 43.

5. Yavuz M, Öztürk S, Ulusoy C, Kecef M, Kabak S, Zeybek R. Hastaların günübirlik cerrahi hakkında düşüncelerinin incelenmesi, 8. Ulusal Cerrahi ve Ameliyathane Hemşireliği Kongresi Kongre Kitabı, Kuşadası Aydın, 2013; 281-289.

6. WEB_1: Türk Dil Kurumu Ana Sayfası. www.tdk.gov.tr

7. Kuğuoğlu S, Karabacak Ü. Genel Konfor Ölçeğinin Türkçe'ye uyarlanması, İstanbul Üniversitesi Florance Nightingale Hemşirelik Dergisi 2008;61(16):16-23.

8. Ocakçı AF, Alpar EŞ. Hemşirelik Kavram, Kuram ve Model Örnekleri, İstanbul Tıp Kitabevi, 1. Baskı, İstanbul 2013, ss 39-57.

9. Çay E, Günübirlik cerrahi girişim sonrası hastaların yaşadıkları sorunların değerlendirilmesi, Yüksek Lisans Tezi, Marmara Üniversitesi Sağlık Bilimleri Enstitüsü Cerrahi Hastalıkları Hemşireliği Anabilim Dalı, İstanbul 2011.

10. Gültürk E. Günübirlik cerrahiye başvuran kadın-doğum hastalarının perioperatif hemşirelik bakım gereksinimleri ve karşılanma durumu, Yüksek Lisans Tezi, Akdeniz Üniversitesi Sağlık Bilimleri Enstitüsü Doğum ve Kadın Hastalıkları Hemşireliği Anabilim Dalı, Antalya 2012.

11. Üstündağ H. 2009, Koroner arter bypass greft cerrahisi uygulanan hastaların konfor düzeyi, Doktora Tezi, Marmara Üniversitesi Sağlık Bilimleri Enstitüsü Cerrahi Hastalıkları Hemşireliği Anabilim Dalı, İstanbul 2009.

12. Doğru SY, Arslan E. Engelli çocuğu olan annelerin sürekli kaygı düzeyi ile durumluk kaygı düzeylerinin karşılaştırılması. Selçuk Üniversitesi Sosyal Bilimler Enstitüsü Dergisi, 2008, 19: 543-553.

13. Fındık, ÜY, Topçu Yıldızeli S. Cerrahi girişime alınışşeklinin ameliyat öncesi anksiyete düzeyine etkisi. Hacettepe Üniversitesi Hemşirelik Fakültesi Dergisi 2012;19(2):22-33.

14. Wetsch, Wolfgang A., et al. Preoperative stress and anxiety in day-care patients and inpatients undergoing fast-track surgery. British Journal of Anaesthesia, 2009, 103.2: 199-205.

15. Kolcaba K, Dimarco MA. Comfort theory and it's application to pediatric nursing. Pediatric Nursing 2005; 31(3):187-194. 
16. Erdemir F, A Çırlak A. "Rahatlık kavramı ve hemsirelikte kullanımı [The concept of comfort and its utilization in nursing]." Dokuz Eylül Üniversitesi Hemşirelik Yüksekokulu Elektronik Dergisi 2013;6(4): 224-230.

17. Rosen HI, Bergh IH, Lundman BM, Martensson LB. Patients' experiences and perceived causes of persisting discomfort following day surgery. BMC Nursing, 2010;9(1).

18. Gürçayır D. Kalça protezi ameliyatı olacak hastalara verilen eğitimin ameliyat sonrası konfor düzeyi ve günlük yaşam aktivitelerine etkisi. Atatürk Üniversitesi Sağlık Bilimleri Enstitüsü Cerrahi Hastalıkları Hemşireliği Anabilim Dalı Yüksek Lisans Tezi. Erzurum 2011.

19. Akkaş Gürsoy A, Ameliyat öncesi hastaların kaygı düzeyleri ve kaygıya neden olabilecek etmenlerin belirlenmesi, Hemşirelik Araştırma Dergisi 2001;1:23-29 